\title{
SIMILARITIES AND DIFFERENCES IN DUNE HABITATS BETWEEN TUSCAN AND DOBROGEAN COASTS (NORTH-WESTERN ITALY VERSUS ROMANIA \& NORTHERN BULGARIA)
}

\author{
Andrea BERTACCHI ${ }^{1}$, Marius F $\breve{A G A R A S S^{2}}$ \\ ${ }^{1}$ Department of Agriculture, Food and Environment (DAFE), University of Pisa, Via del Borghetto 80, \\ I-56124 Pisa, Italy \\ ${ }^{2}$ Ovidius University, Faculty of Natural and Agricultural Sciences, Aleea Universitatii 1 B, \\ RO-900527 Constanţa, Romania \\ e-mail: andrea.bertacchi@unipi.it
}

\begin{abstract}
We report and compare the foredune habitats of some areas located along the coasts of Tuscany (It) and Dobrogea (Ro, $\mathrm{Bu}$ ), focusing on the floristic and phytocoenotic features, through phytosociological surveys carried out along the two coasts, very different from the biogeographical point of view. Both coasts are about 300 $\mathrm{km}$ long and have approximately $200 \mathrm{~km}$ of sandy beaches. Among dune habitats (sensu Directive 92/43/EEC) only those of the foredunes (upper beach and mobile dunes) seemed to be shared. The comparison of phytosociological relevés performed in the two areas and concerning these foredune habitats, have highlighted: a) a high floristic and phytocoenotic diversity even in the same habitats of the two different sandy coasts; b) a tendency for the floristic differences to increase from ephemeral dune habitats (annual vegetation of drift lines) to the inner dunes (white dunes); c) diagnostic species of habitats are shared significantly only for habitat 1210 .
\end{abstract} 92/43/EEC

Keywords: Psammophilous plants, Phytogeography, Sands, Tuscany coasts, Black Sea coasts, Directive

\section{Introduction}

Sandy coastal environments, at the landscape scale, are characterized by shared geomorphological, ecological and vegetational elements. These can be summarized as follows: close proximity to the marine environment, effect of the sea on microclimate, constant modelling by wind, waves and tides, salty air, sediment size, high permeability of the soils and shortage of nutrients, and great brightness [39, 21,31]. All these factors select a flora and vegetation with common ecological characteristics (psammophilous plants) and, often, the same species grow in widely separated geographical areas [51]. In this context, equally well known and described is a well-defined zonation of vegetation from shoreline to the inside of the beach-dune system, shaped by the variation in apparently minimal environmental changes [19, 41, 1, 25, 14, 17]. Where unaltered by anthropogenic modifications or erosion $[6,5]$, this environment results in the presence of many habitats, different in species and plant communities, often within the space of a few metres $[43,2]$. All this means that in Europe, at the landscape scale, the coastal strip consistently has few and common habitats, despite the great coenological diversity that has been described [37, 54].

The 'Habitats Directive' 92/43/EEC of the European Union aims to create a coherent network under the framework of Natura 2000, to protect the unique natural European heritage, 
and in Annex I of the 92/43/EEC directive, 20 coastal sedimentary habitats have been identified and described [54]. Eleven of these can be strictly correlated with beach and dune environments: Habitats 1210, 2110, 2120, 2130, 2160, 2210, 2230, 2240, 2250*, 2260, 2270*. Nevertheless, only $\mathrm{H} 1210, \mathrm{H} 2110$ and $\mathrm{H} 2120$, are those habitats that better represent the foredune - the area between the shoreline and the dune crests [4] - and those more frequently present all along the European sedimentary coasts. Each habitat is essentially characterized by few diagnostic species and/or phytosociological syntaxa $[2,10,28]$ and it is of utmost importance to identify similarities or differences of the same dune habitats of European coasts, not only for better scientific knowledge but also for a better possibility of conservation and management [15, 47].

As part of a geobotanical research project in the Mediterranean environment (DAFE Project, University of Pisa), it seemed to be of great interest to investigate and compare the floristic and phytocoenotic features of the foredune environments belonging to the same habitats of two European coastal areas very different from the biogeographical point of view: the coast of Tuscany (Italy, Mediterranean Region, Italo-Tyrrenian province), and the coast of Dobrogea, a cross-border coastal strip located on the western zone of the Black Sea, both in Romania (the northern part) and Bulgaria (the southern part) (Eurosiberian Region, Escitian province (Fig. 1).

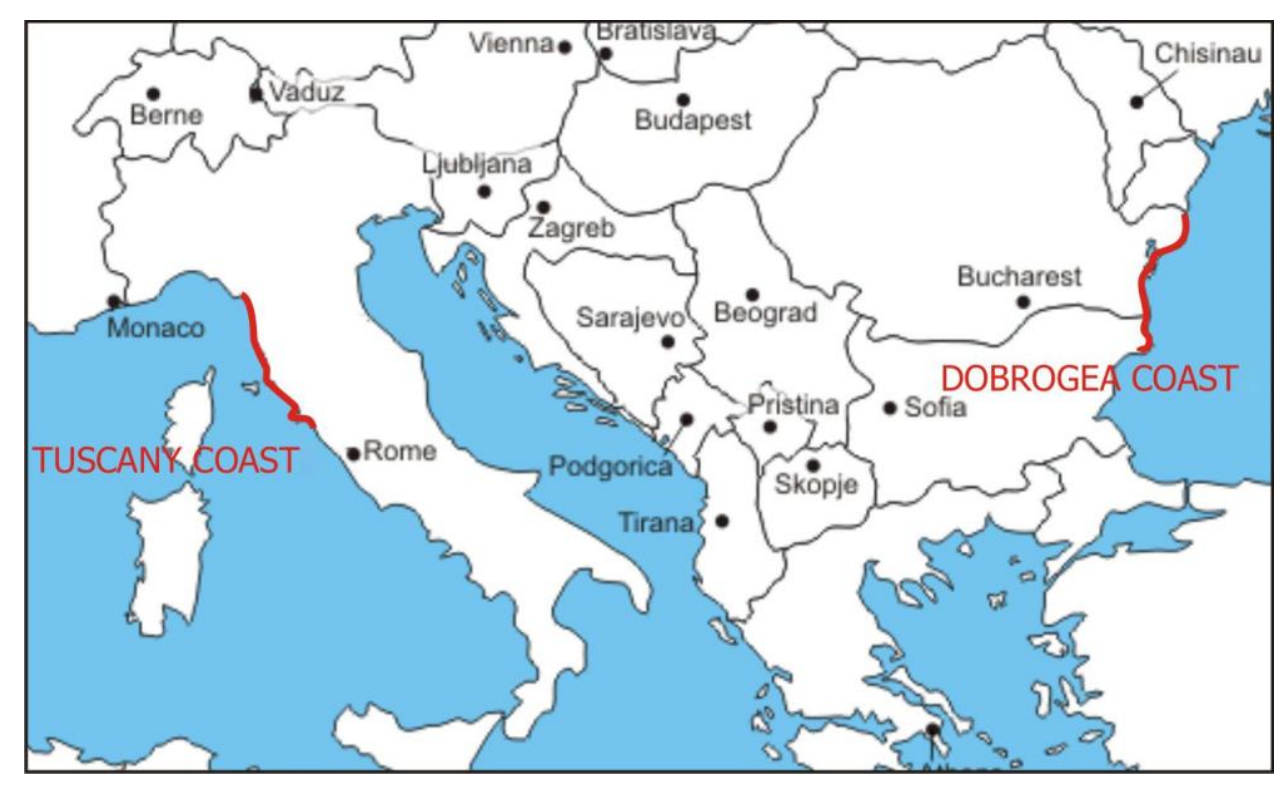

Fig. 1: Location of the study areas in the two biogeographical regions

Although, at the present day, the use of large data sets of published phytosociological surveys for comparison of different regions is increasingly used [33, 16, 3, 11], the opportunity for surveys carried out by the same operators on such different regions has stimulated us to work to this end.

Given that the data already available in the literature $[28,26,50]$ have shown that the only dune environments shared between the two regions are those related to the foredunes, and, consequently, limiting the field of investigation and comparison only to this, the questions were: 1- which foredune habitats were present in the two coasts? 2- what were the floristic-vegetational traits shared for the same habitats and what were the differences? 3- how much was due to the shared/different biogeographical aspects and what to the possible differences in site features? 


\section{Material and Methods}

Study areas and surveys

The mainland coast of Tuscany is situated between $44^{\circ} 01^{\prime} 48^{\prime \prime}-42^{\circ} 23$ ' $24^{\prime \prime} \mathrm{N}$ and $10^{\circ} 03^{\prime}-11^{\circ} 26^{\prime} \mathrm{E}$. The length is about $315 \mathrm{~km}$, of which about $200 \mathrm{~km}$ consists of sandy coasts. The coast of Dobrogea includes all the Romanian coast and part of the northern coast of Bulgaria between $45^{\circ} 06^{\prime} 36^{\prime \prime}-43^{\circ} 22^{\prime} 12^{\prime \prime} \mathrm{N}$ and $29^{\circ} 42^{\prime}-28^{\circ} 30^{\prime} \mathrm{E}$. The total length is approximately 290 $\mathrm{km}$ (until Cape Kaliakra), about $265 \mathrm{~km}$ of which is sandy coasts. The most important morphological, physico-chemical and climatic features of the two foredune environments are shown in Tab.1. From a bioclimatic point of view, according to the bioclimatic classification of Rivas-Martinez \& Rivas-Saenz [45] the two regions are both included in a Mediterranean macrobioclimate even if quite different: Mediterranean pluviseasonal oceanic (Tuscany) and Mediterranean pluviseasonal continental steppic (Dobrogea).

For identification of the habitats and analysis of the floristic and phytocoenotic similarities and differences, phytosociological surveys were carried out in the late spring of 2016, along nine different areas of the coast of mainland Tuscany (63 relevés) and in the late spring of 2017, along the Dobrogea coast (60 relevés) in seven different areas (Fig. 2).

The relevés, from a minimum of $5 \mathrm{~m}^{2}$ to a maximum of $50 \mathrm{~m}^{2}$, have been recorded using the systematic method of the Zurich-Montpellier school [12], only on the psammophilous vegetation of the foredune, excluding the inland areas of the stabilized dunes. The identification (sensu directive 92/43/EEC) and comparison of habitats has concerned exclusively: H1210 (Annual vegetation of drift lines); H2110 (Embryonic shifting dunes); H2120 (Shifting dunes along the shoreline with Ammophila arenaria (white dunes).

\section{Data analysis}

In order to compare and classify the floristic characteristics of each habitat on both coasts and the frequency and the fidelity of the species, releve data were analyzed with Juice 7.0 software (matrix of 63 species x 123 relevés). Cluster analysis, using UPGMA and Bray-Curtis index [13] were assessed with PAST 3.14 software [30]. Regarding the estimation of the dissimilarity between the habitats of the two regions, Non-Metric Multidimensional Scaling (NDMS) with the Bray-Curtis coefficient as the similarity measure was performed with PAST 3.14 on the whole data set. Fidelity phi coefficient was as proposed by Tichy'\& Chytry' [49]. Diagnostic species of Tuscany habitats have been determined according to Biondi \& Blasi [10], Biondi et al. [9] and Acosta \& Ercole [2]. For Dobrogea, diagnostic species of the habitats have been considered according to Donita et al. [20], Fagaras [26] and Tzonev et al. [50]. Nomenclature of the taxa was according to the Euro+Med [53] data base. Species chorology and life forms are according to Pignatti [40] for the flora of Tuscany and to Sârbu et al. [46], Dihoru $\&$ Negrean [18] for the flora of Dobrogea.

\section{Results}

Flora

As a result of field surveys, 55 plant species for Tuscany and 62 plant species for Dobrogea have been found (Tab. 2). The reported species are strictly associated if not almost exclusively linked to the dune environments and represent the cohort of species found at least once within the surveys. A marked difference in chorological spectrum was evident with a clear 
biogeographical differentiation: a dominance of Mediterranean species along Tuscan sandy coasts, and a strong presence of European, Euro-siberian, Pontic and, overall, Black Sea Littoralic species for Dobrogea. Also from the point of view of the life forms [44], there was a clear difference between the two coastal regions: while for the Tuscan coasts there was a prevalence of therophytes and camephytes (respectively $40 \%$ and $18 \%$ ), for the Dobrogea coasts, hemicriptophytes were the most represented (51\%) (Tab. 2, Fig. 3). The overall comparison of the floristic data of Tuscany and Dobrogea foredune environments showed a very limited number of shared species: 10 species were overall shared in common, although three of these (Cakile maritima, Salsola kali, Elymus farctus) belonged to different subspecies (Tab. 3). Considering the species with a sharing frequency of at least $30 \%$, the number decreased to only five species (Tab. 4).

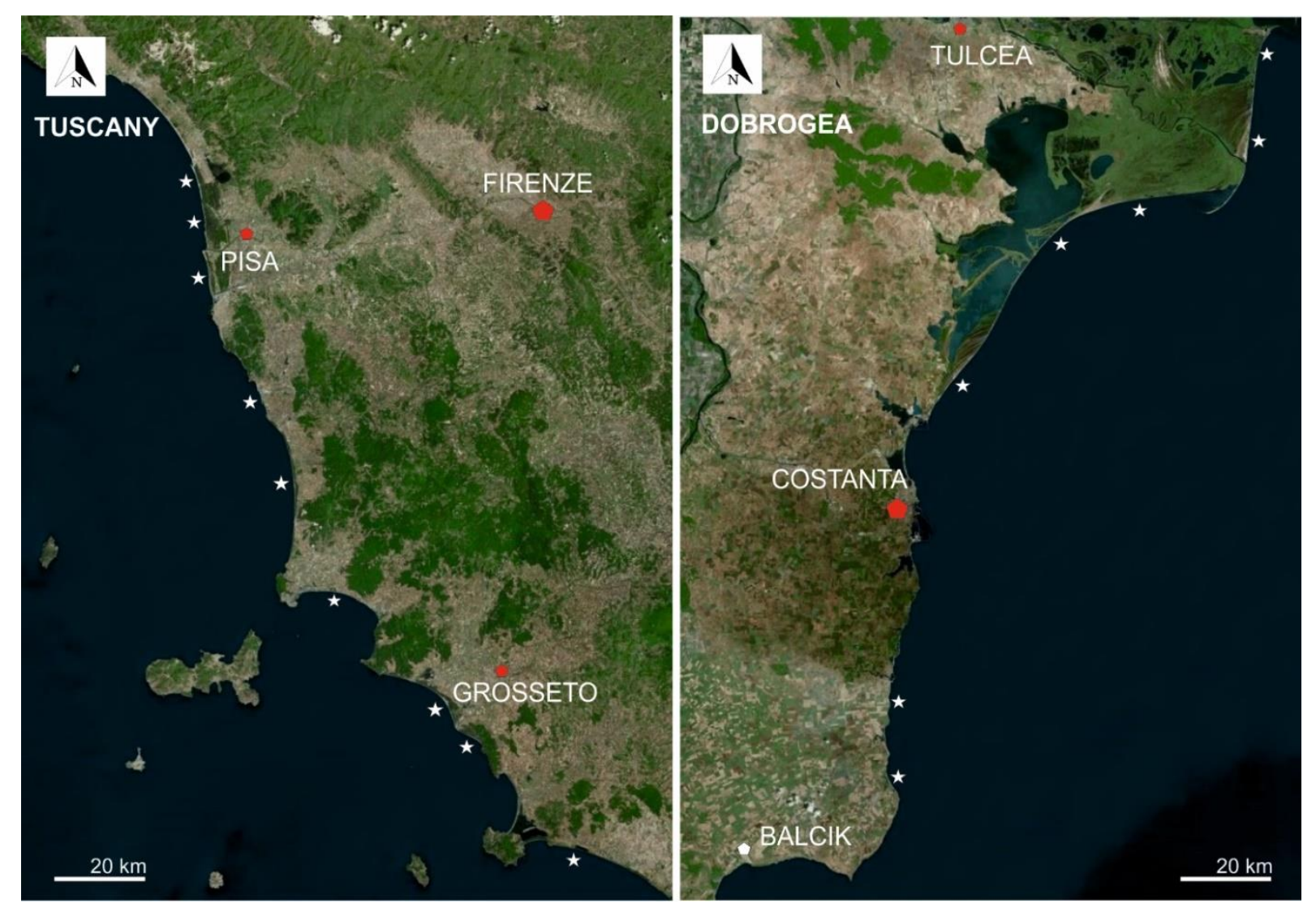

Fig. 2: Satellite images of the two coasts with location of survey areas ( h $\hat{\zeta}^{\text {) }}$

Vegetation and Habitats

Cluster analysis of phytosociological data (not shown here), showed a significant split basically between three phytocoenotic groups (Habitats) for each region (Fig. 4), while the synoptic table built with Juice 7.0 software (Table 3), revealed several diagnostic species whose presence allowed the identification of four associations for Tuscany and three for Dobrogea. These phytocoenoses were largely attributable to the following associations: Salsolo kaliCakiletum maritimae Costa e Manzanet 1981 nom. mut. propos. in Rivas-Martínez et al. 2002, (H1210) Sporobolo arenarii-Agropyretum juncei (Br.-B1. 1933) Géhu, Rivas-Martinez et R. Tx. 1972 in Géhu et al. 1984, Echinophoro spinosae-Elymetum farcti Géhu 1987 (H2110), Echinophoro spinosae-Ammophiletum australis (Br.-B1. 1933) Géhu, Rivas-Martinez \& R. Tx. 
1972- in Géhu et al. 1984 for Tuscany; Cakilo euxinae-Salsoletum ruthenicae Vicherek 1971, Elymetum gigantei Morariu 1957 and Medicago tenderiensis-Ammophiletum arundinaceae Tzonev et al. 2005 for Dobrogea (the last plant community only on the Bulgarian coast). Consequently, three types of foredune habitats were identified for each region: H1210, H2110, H2120 (Tab. 3). Habitat 2120 has been observed only on the coast of Tuscany and along the coast of northern Bulgaria (southern Dobrogea). These habitats, when considering the subspecific entities as belonging to the same taxa, proved to be partly equivalent. Indeed, this similarity with species frequency $>30 \%$, was linked to two diagnostic species only for habitat 1210 (Cakile maritima, Salsola kali), while for habitat 2120 the diagnostic shared species was one only (Ammophila arenaria) and for habitat 2110 the only entity in common was Cakile maritima, although not diagnostic for this habitat. Elymus farctus was paradoxically shared for habitat 2120 but not for its related habitat 2110, where, in Dobrogea, it revealed a very low frequency (Tab. 3, Tab. 4). NDMS analysis showed a significant separation between formally identical dune habitats of the Tuscany and Dobrogea coasts. The homologous Tyrrenian and Black Sea habitats reveal a partial proximity only for habitat 1210. It could also be highlighted that the floristic proximity in the ordination space was larger for two of the Tuscany habitats (2110 and 2120) than for those of Dobrogea with a maximum floristic similarity between the Tuscany embryonic shifting dunes (2110) and white dunes with Ammophila arenaria (2120). The Dobrogea coastal dunes, on the contrary, were relatively independent of each other (Fig. 5).

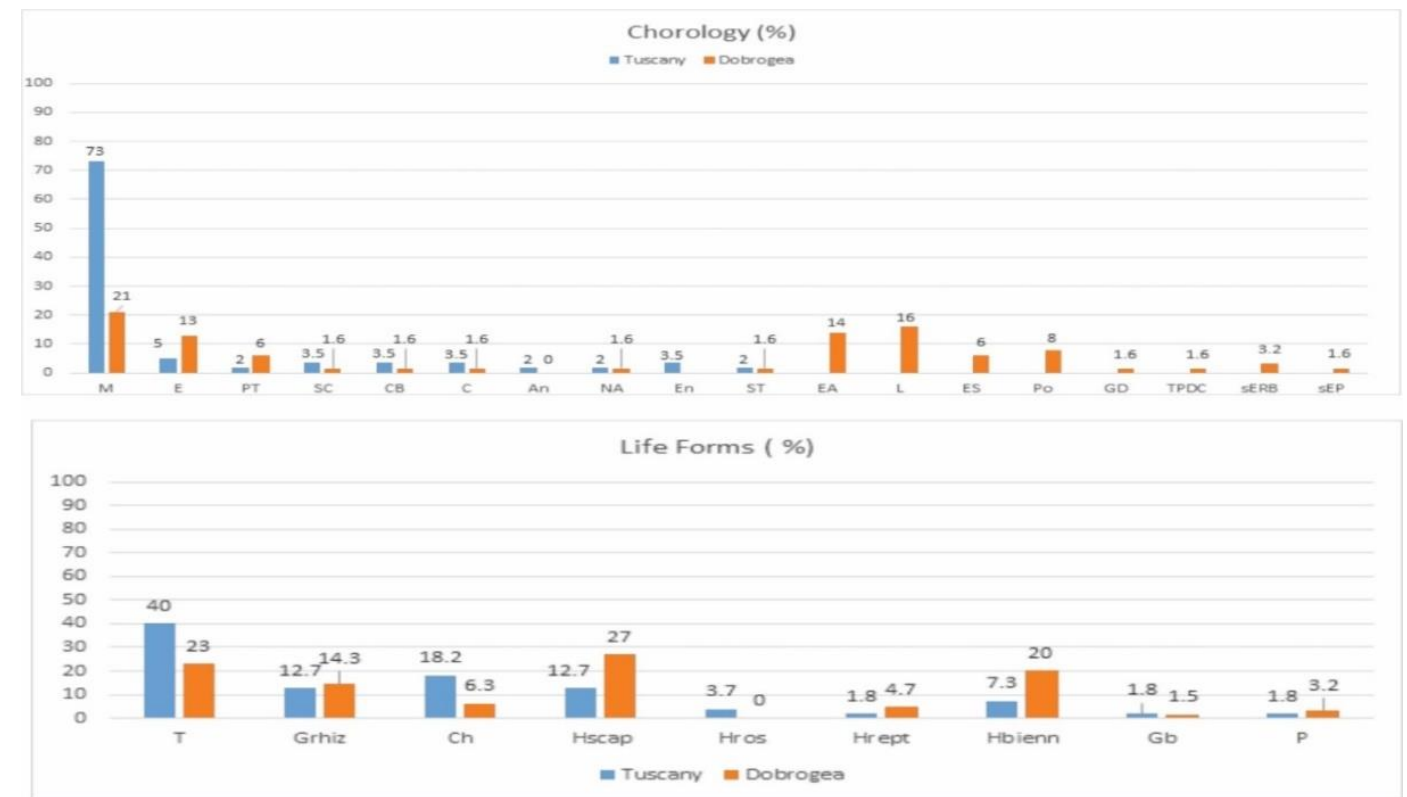

Fig. 3: Chorology and life forms of taxa in foredune surveys of Tuscany and Dobrogea sandy coasts.

Chorology - M : Mediterranean (Mediterranean-Atlantic, Eurimediterranean, Stenomediterranean, W Mediterranean, Mediterranean Turanic, Mediterranean Pontic); CB: Circumboreal; PT: Paleotemperate; E (European, S European, Europ- Caucas, E and SE European); An: Amfi-Atlantic; En: Endemic C: Cosmopolitan; SC: Subcosmopolitan; ST: Subtropical; NA: N American; L: Littoralic (Littoralic-Black Sea, Littoralic-Black Sea and Dagestan, Littoralic-Black Sea and Caspian Sea); EA: Eurasian, Continental Eurasian; ES: Euro-Siberian; Po: Pontic (Pontic-Panonic-Balkanic, Pontic-Panonic, Pontic-Mediterranean); GD: Getic-Dobrogean; TPDC: Tauric-Ponto-Dobrogean-Caspic; sERB: sub-Endemic (Romania, Bulgaria); sEP: sub-Endemic-Pontic;

Life forms - T : therophyte; Grhiz: rhizomatous geophyte; Ch: chamaephyte; Hscap, Hros, Hrept, Hbienn: hemicryptophyte (with stem, only with rosette only; creeping; biennial) ; Gb: bulb geophyte; P: phanerophyte 

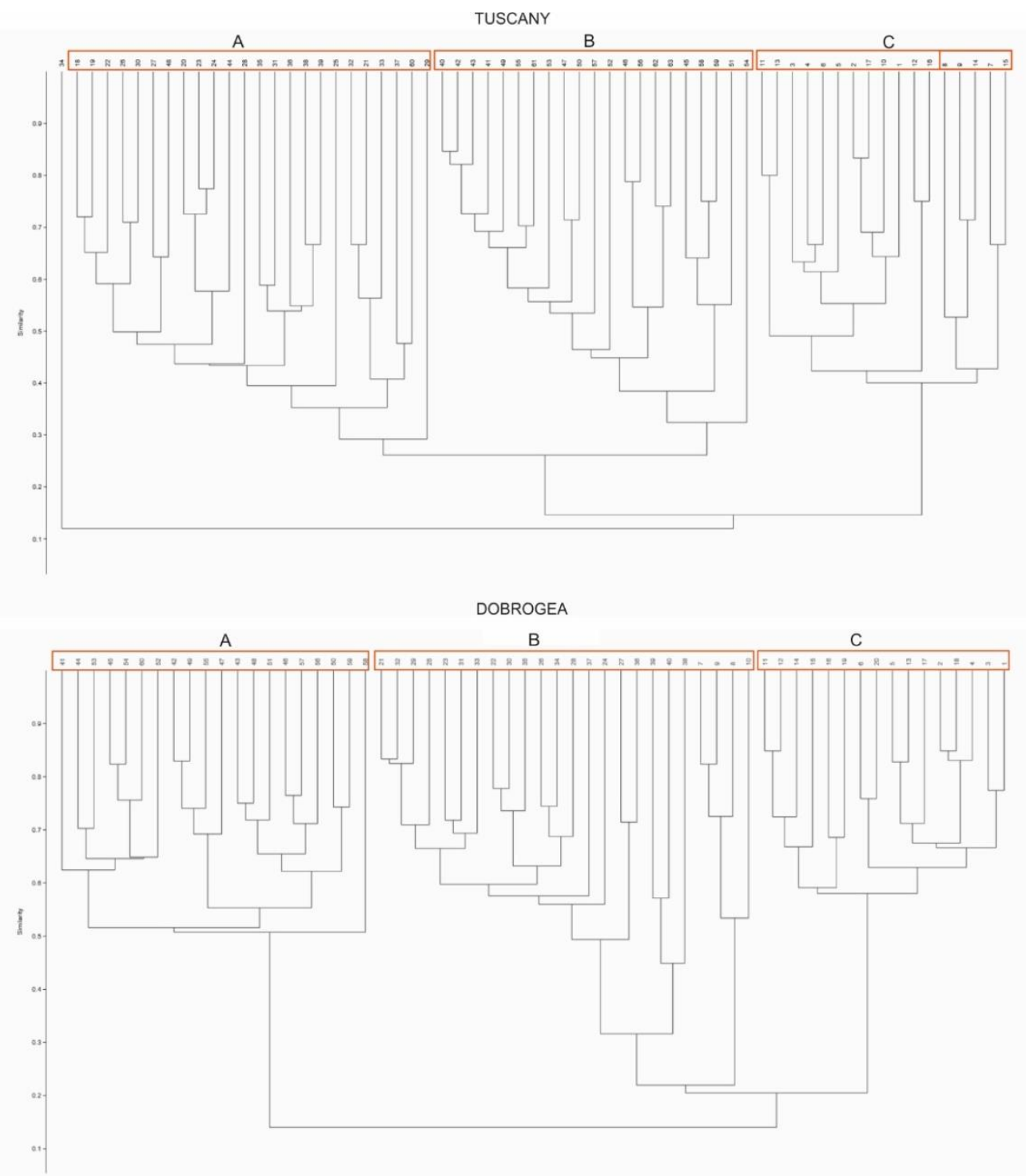

Fig. 4: Cluster analysis of Tuscany and Dobrogea surveys (A: H1210; B: H2110; C: H2120)

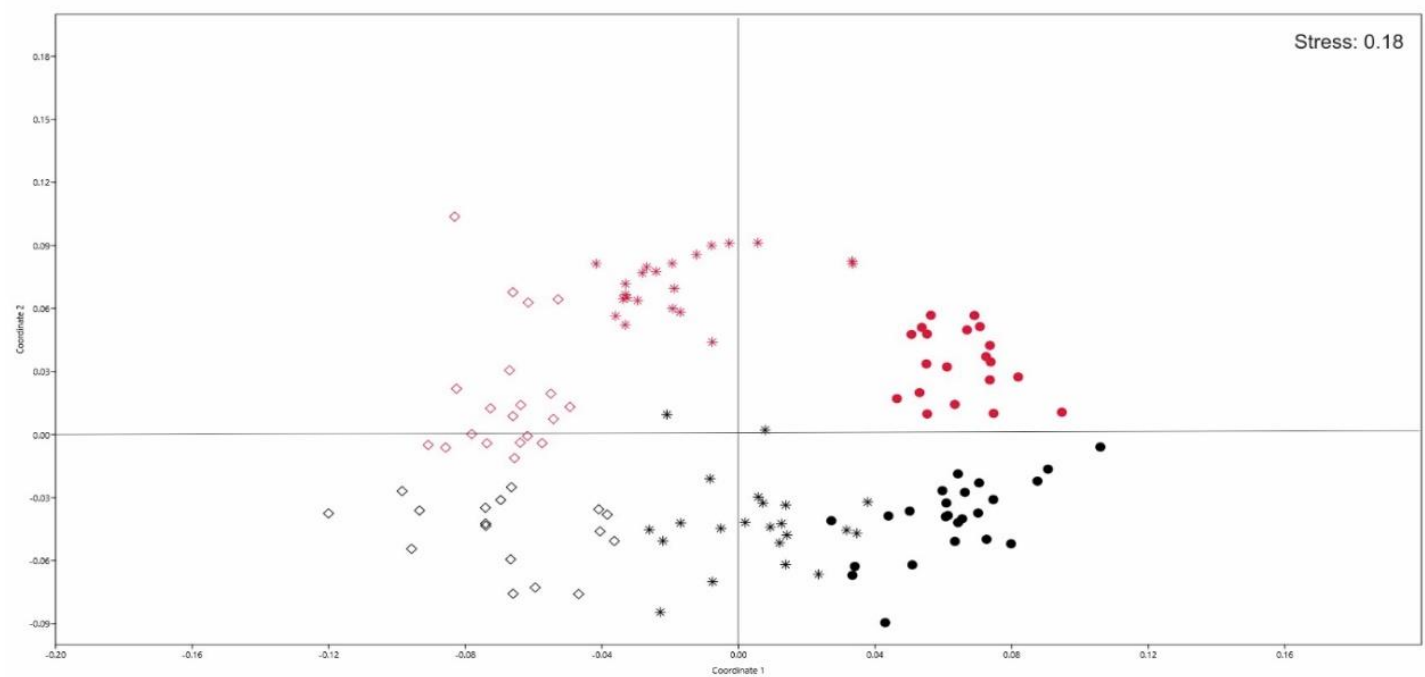

Fig. 5: NDMS ordination of vegetation plots from two regions ( Tuscany : (habitat 1210, 4 habitat 2110, \# habitat 2120); Dobrogea : (habitat 1210, 4 habitat 2110, \# habitat 2120) 


\section{Discussion}

The dune environments and, above all, the foredunes fall within the typology of extreme environments [35] where stress-inducing ecological factors (sand burial, salinity, drought, lack of soil and nutrients, wind and flooding by the sea) greatly influence the vegetation composition and structure [38]. As a consequence, species and plant communities are selected by the stressful ecological conditions, much more than by the bioclimate, and the more stressful a habitat the more its vegetation is habitat-related and independent of the biogeographical region [29, 34]. This is why, very often, there are convergences among taxa present in these environments, even on a large scale [19]. In our case study, this type of convergence is very limited and important differences in climatic factors and site features coexist (Tab. 1). These differences are reflected in the different chorology, life forms and number of species shared between the sandy coasts of Tuscany and Dobrogea, even when the same habitats were present. Chorology: The evident chorological difference between the two regions, already highlighted in the results, is undoubtedly linked to the presence of the species (52\% of total Dobrogea species) with focal point on the Black-Sea Region and whose distribution area is never superimposable on that of the Tuscany coast species. Among Mediterranean species present on both coasts, only four were shared (Tab. 2). Life forms: in this case, the differences are evidently bound to the different bioclimatic characteristics of the two regions. For the Tuscany coasts, the percentage values of the life forms showed a substantial dominance of the therophytes, which is a datum consistent with the Mediterranean bioclimate and dune environments [32]. The prevalent life form of the coastal Dobrogea species was instead given by the hemicriptophytes, which is a datum coherent with the Eurosiberian region and a steppic environment [22]. Shared species: the greater sharing of species appears to be linked to the habitat 1210 (Annual vegetation of drift lines). In this case, stress factors such as lack of nutrients and extreme mobility of the substratum, on those of a biogeographical type, seemed to prevail and to select a range of species more similar than in the other habitats. It is interesting to note that in this habitat, similar ecological characteristics (extreme proximity to the sea, lack of nutrients) and dissimilar (such as the average tidal range and, overall, the average salinity of the sea) coexist in the two regions. This may be the explanation of why in Tuscany, with an average salinity of the sea around 33\%o, and a tidal range of $0.20 \mathrm{~m}$, the habitat 1210 is on average less rich in species ( 5 on average) than the homologue of Dobrogea ( 8.5 on average), a region washed by a sea with an average salinity of $17 \%$ and minor tidal range $(0.08 \mathrm{~m})$ (Tab. 4). Moving away from the upper beach to the inner mobile dunes, the limited sharing tends to quickly cancel out in the same way, as the average number of species per habitat becomes similar. Here the different bioclimatic factors - much lower temperature and rainfall in Dobrogea than in Tuscany (Tab. 1) - overtake edaphic or morphological features of the site and an evident floristic-vegetational diversity emerges.

\section{Conclusions}

Despite that there was a formal identification of three homologous foredune habitats, based on the diagnostic species considered for each region, a high difference in flora and vegetation has been detected. Although the number of detections was relatively low, it appeared to be sufficient to highlight the growing dissimilarities, proceeding from habitat 1210 towards the interior of the dune system. From the data collected, only habitat 1210 can be considered the same for the two coastal regions. For the other two habitats the floristic-vegetational differences 
become such as to prevent, in our opinion, their homology within the same habitat, and, albeit the prevalent morphology of the foredune appears different between the two coasts as well as some ecological traits, these differences seem to be related overall to the different bioclimatic context. According to European Directive 92/43/EEC, habitat identification is mainly related to the presence of specific associations or alliances, in turn due to the presence or absence of diagnostic species [23, 24, 54]. Obviously, each member country has tried to clarify and resolve some problems concerning uncertain attribution and misinterpretation of habitats. Regarding the member countries related to the present research (Italy, Romania, Bulgaria), Biondi et al. [8], Gigante et al. [28], Donita et al. [20], Fagaras [26] and Tzonev et al. [50], have, in a more or less detailed way, contributed to improving the interpretation. The problem is that which concerns the inclusion of floristically different environments in the same habitats, at least according to the EU Directive. This has already manifested itself with regard to the same European habitats of Mediterranean and Atlantic environment, where other but also important differences for Habitats 2110 and 2120, and the introduction of new identification codes has been suggested [27]. Regarding Habitat code, it is certainly worth highlighting for us that several differences exist within Europe, at regional level. Indeed, EUNIS Habitat classification [52] seems, at least for the European coastal environments, to better highlight these regional differences, distinguishing for each biogeographical region a specific habitat.

Table 1: Physical and climatic characteristics of the two study areas

\begin{tabular}{l|c|c|c|c|c|c|c}
\hline REGION & $\begin{array}{c}\text { Foredune } \\
\text { Width } \\
\text { (min-max in } \mathrm{m})\end{array}$ & $\begin{array}{c}\text { Foredune } \\
\text { Height } \\
(\text { minmax in } \mathrm{m})\end{array}$ & $\begin{array}{c}\text { Sands } \\
\text { composition and } \\
\mathrm{pH}\end{array}$ & $\begin{array}{c}\text { Sea } \\
\text { salinity }\end{array}$ & $\begin{array}{c}\text { Max tide } \\
\text { level in } \\
\text { metres }\end{array}$ & $\begin{array}{c}\text { T C } \\
(\text { annual } \\
\text { average })\end{array}$ & $\begin{array}{c}\text { Rain } \\
(\mathrm{mm})\end{array}$ \\
\hline $\begin{array}{l}\text { Tuscany } \\
\text { coasts }(*)\end{array}$ & $20-150$ & $2-10$ & Quarzolithic $\simeq 7$ & $33 \% 0$ & 0.20 & 15,2 & 790 \\
\hline $\begin{array}{l}\text { Dobrogea } \\
\text { Coasts }(* *)\end{array}$ & $12-85$ & $0.5-3$ & $\begin{array}{c}\text { Biogenic origin } \\
(\text { shells }) \simeq 8\end{array}$ & $17 \%$ o & 0.08 & 11,9 & 420 \\
\hline
\end{tabular}

Legend: (*) [42, 7]; thermo-pluviometric data 1989-2010 : Meteorological station of Cecina (LI).

(**) [25, 36]; thermo-pluviometric data 1980-1999: Meteorological station of Costanta.

Table 2: Floristic list of the species found in the two regions

\begin{tabular}{|c|c|}
\hline Tuscany (55 spp.) & $\begin{array}{l}\text { Dobrogea (in Romania and Northern } \\
\text { Bulgaria) (63 spp.) }\end{array}$ \\
\hline Achillea maritima (L.) Ehrend \& Y.P. Guo M Ch & Aeluropus littoralis (Gouan) Parl. M Grhiz \\
\hline $\begin{array}{l}\text { Ammophila arenaria (L.) Link subsp. arundinacea } \\
\text { H.Lindb. M Grhiz }\end{array}$ & $\begin{array}{l}\text { Ammophila arenaria }(\mathrm{L} .) \text { Link subsp. } \\
\text { arundinacea } \text { H.Lindb. M Grhiz }\end{array}$ \\
\hline Hordeum murinum L. CB T & $\begin{array}{l}\text { Alyssum borzaeanum Nyár. (= Odontarrhena } \\
\text { borzaeana (Nyár.) D. A. German } \mathbf{L} \text { Ch }\end{array}$ \\
\hline Anthemis maritima L. M Hscap & Alyssum hirsutum M.Bieb. EA Hscap \\
\hline Pheum arenarium $\mathrm{L} . \mathbf{M}$ T & Alyssum minutum Schltdl. ex DC M T \\
\hline Atriplex prostrata Boucher ex DC CB $\quad$ T & Anchusa officinalis L. Po Hscap \\
\hline $\begin{array}{l}\text { Bromus madritensis L. (=Anisantha madritensis } \\
\text { (L.) Nevski M T }\end{array}$ & Argusia sibirica (L.) Dandy L Hscap \\
\hline Cakile maritima Scop. subsp. maritima $\mathbf{M ~ T}$ & Aristolochia clematitis L. M G \\
\hline $\begin{array}{l}\text { Calystegia soldanella (L.) Roem \& Schult. C } \\
\text { Grhiz }\end{array}$ & Artemisia tschernieviana Besser ES $\mathbf{C h}$ \\
\hline Catapodium rigidum (L.) C.E. Hubb. M T & Astragalus varius S.G. Gmel. EA Ch \\
\hline Euphorbia peplis L. M T & Astrodaucus littoralis (Bieb.) Drude L Hbienn \\
\hline
\end{tabular}




\begin{tabular}{|c|c|}
\hline $\begin{array}{l}\text { Centaurea paniculata L. subsp. subciliata (DC.) } \\
\text { Arrigoni En Hbienn }\end{array}$ & Atriplex prostrata Boucher ex DC CB \\
\hline Crepis vesicaria L. M Hbienn & Bassia hirsuta (L.) Asch E T \\
\hline Crithmum maritimum L. M Ch & Bromus squarrosus L. PT T \\
\hline Crucianella maritima L. M Ch & $\begin{array}{l}\text { Bromus tectorum L. (Anisantha tectorum (L.) } \\
\text { Nevski PT T }\end{array}$ \\
\hline Cutandia maritima (L.) Benth. ex Barbey M T & Carex colchica J. Gay EA Grhiz \\
\hline $\begin{array}{l}\text { Cuscuta australis subsp. cesatiana (Bertol.) O. } \\
\text { Schwarz NA T }\end{array}$ & $\begin{array}{l}\text { Cakile maritima Scop. subsp. euxina (Pobed.) } \\
\text { Nyár. L T }\end{array}$ \\
\hline Cynodon dactylon (L.) Pers. C Grhiz & $\begin{array}{l}\text { Centaurea arenaria subsp. borysthenica } \\
\text { (Gruner) Dostál Po Hbienn }\end{array}$ \\
\hline $\begin{array}{l}\text { Daucus carota ssp. maritimus (Lam.) Batt. M } \\
\text { Hbienn }\end{array}$ & Cerastium brachypetalum Pers. M T \\
\hline $\begin{array}{l}\text { Dittrichia viscosa (L.) Greuter ssp. viscosa } \mathbf{M} \\
\text { Hscap }\end{array}$ & Cerastium semidecandrum L. EA T \\
\hline Echinophora spinosa L. M Hscap & Euphorbia peplis L. $\mathbf{M} \mathbf{T}$ \\
\hline $\begin{array}{l}\text { Elymus farctus (Viv.) Runemark ex Melderis } \\
\text { subsp. farctus } \quad \text { M Grhiz }\end{array}$ & Chondrilla juncea L. E Hscap \\
\hline Eryngium maritimum L. M Grhiz & Convolvulus persicus L. L Hscap \\
\hline Euphorbia paralias L. M Ch & $\begin{array}{l}\text { Conyza canadensis (L.) Cronq.(=Erigeron } \\
\text { canadensis L.) NA T }\end{array}$ \\
\hline $\begin{array}{l}\text { Fumana procumbens (Dunal) Gren. \& Godr M } \\
\text { Ch }\end{array}$ & Corispermum nitidum Kit. Po Hbienn \\
\hline Glaucium flavum L. M Hscap & Crambe maritima L. L Hscap \\
\hline Helichrysum stoechas (L.) Moench M Ch & $\begin{array}{l}\text { Crepis foetida subp. rhoedifolia (M. Bieb.) } \\
\text { Čelak. E Hbienn }\end{array}$ \\
\hline & Cynanchum acutum L. ST PI \\
\hline Hypochaeris radicata L. E Hros & Cynodon dactylon (L.) Pers. C Grhiz \\
\hline $\begin{array}{l}\text { Jacobaea maritima (L.) Pelser \& Meijden subsp. } \\
\text { maritima } \mathbf{M} \mathbf{C h}\end{array}$ & $\begin{array}{l}\text { Elymus farctus (Viv.) Runem. ex Melderis } \\
\text { subsp. bessarabicus (Săvul et Rayss) Melderis } \\
\text { L Grhiz }\end{array}$ \\
\hline $\begin{array}{l}\text { Juniperus oxycedrus L. subsp. macrocarpa (S.et } \\
\text { S.) Ball M P }\end{array}$ & Erysimum diffusum Ehrh. E Hscap \\
\hline Lagurus ovatus L. M T & Eryngium maritimum L. M Grhiz \\
\hline Limbarda crithmoides (L.) Dumort M Ch & Euphorbia seguieriana Neck ES Hscap \\
\hline Malcolmia ramosissima (Desf.) Thell. $\mathbf{M} \mathbf{T}$ & $\begin{array}{l}\text { Festuca beckeri (Hackel) Trautv. subsp. } \\
\text { arenicola (Prodan) Soó Po Hcaesp }\end{array}$ \\
\hline Matthiola tricuspidata (L.) R.Br. M T & $\begin{array}{l}\text { Glaucium flavum Crantz subsp. flavum } \mathbf{M} \\
\text { Hscap }\end{array}$ \\
\hline Medicago littoralis Loisel $\mathbf{M} \quad \mathbf{T}$ & Gypsophila perfoliata L. L Ch \\
\hline Medicago marina L. M $\mathbf{C h}$ & Hippophae rhamnoides L EA P \\
\hline Oenothera biennis L. SC Hbienn & Lactuca tatarica (L.) C.A. Mey EA Hbienn \\
\hline Ononis variegata L. M T & $\begin{array}{l}\text { Leymus racemosus (Lam.) Tzvelev subsp. } \\
\text { sabulosus (M. Bieb.) Tzvelev. sEP Grhiz }\end{array}$ \\
\hline Pancratium maritimum L. M Gbulb & $\begin{array}{l}\text { Linaria genistifolia subsp. euxina (Velen.) } \\
\text { Delip. sERB Hscap }\end{array}$ \\
\hline Plantago arenaria Waldst. \& Kit. $\mathbf{E} \quad \mathbf{T}$ & $\begin{array}{l}\text { Medicago falcata subsp. tenderiensis (Klokov) } \\
\text { Vassilcz. M Hscap }\end{array}$ \\
\hline Plantago coronopus L M T & $\begin{array}{l}\text { Melilotus arenaria } \text { Grecescu }(=\text { Melilotus } \\
\text { officinalis (L.) Lam.) EA Hbienn }\end{array}$ \\
\hline Polygonum maritimum L. SC Hrept & Onosma arenaria Waldst. \& Kit. E Hscap \\
\hline Pseudorlaya pumila (L.) Grande M T & Papaver rhoeas L. M T \\
\hline Raphanus raphanistrum L. M T & Petasites spurius (Retz.) Rchb. EA Grhiz \\
\hline
\end{tabular}




\begin{tabular}{|c|c|}
\hline Reichardia picroides L. Roth M Hscap & Picris hieracioides L. ES Hbienn \\
\hline Salsola kali L. subsp. tragus (L.) Celak PT T & Plantago arenaria Waldst. \& Kit $\mathbf{E} \mathbf{T}$ \\
\hline Silene colorata Poir. $\mathbf{M ~ T}$ & Polygonum maritimum L. SC Hrept \\
\hline Silene otites (L.) Wibel M Hros & $\begin{array}{l}\text { Polygonum oxyspermum C.A. Mey et Bunge ex } \\
\text { Ledeb. subsp. raii (Bad.) D.A. Webb et Chater. } \\
\text { (=Polygonum euxinum Chrtek, P. mesembricum } \\
\text { Chrtek.) L Hrept }\end{array}$ \\
\hline Solidago litoralis Savi En (Tuscany) Hscap & $\begin{array}{l}\text { Salsola kali L. subsp. ruthenica (Iljin) Soó } \\
\text { PT T }\end{array}$ \\
\hline Spartina versicolor Fabre An Grhiz & Scabiosa argentea L. ES Hbienn \\
\hline Sporobolus virginicus Kuntz ST Grhiz & Scolymus hispanicus L. M Hbienn \\
\hline Teucrium polium L. M Ch & Secale sylvestre Host EA Grhiz \\
\hline Vulpia fasciculata (Forssk.) Fritsch M T & Seseli tortuosum L. M Hbienn \\
\hline Urospermum dalechampii (L.) Schmidt M Hscap & $\begin{array}{l}\text { Silene borysthenica (Gruner) Walters } \mathbf{E} \\
\text { Hbienn }\end{array}$ \\
\hline \multirow[t]{8}{*}{ Xanthium italicum Moretti $\mathbf{E} \quad \mathbf{T}$} & Silene conica L. PT T \\
\hline & Silene thymifolia $\mathrm{Sm}$ L Hrept \\
\hline & Stachys atherocalyx K. Koch TPDC Hscap \\
\hline & Stachys maritima Gouan M Hscap \\
\hline & Verbascum banaticum Schrad GD Hscap \\
\hline & $\begin{array}{l}\text { Verbascum purpureum (Janka) Hub.-Mor. } \\
\text { sERB Hbienn }\end{array}$ \\
\hline & Xanthium italicum Moretti E $\mathbf{T}$ \\
\hline & Xeranthemum annuum L. Po $\mathbf{T}$ \\
\hline
\end{tabular}

Legend: (simplified, according to Pignatti [40] for Tuscany flora and to Sârbu et al. [46] and Dihoru \& Negrean [18] for Dobrogea flora)

Chorology - M: Mediterranean (Mediterranean-Atlantic, Eurimediterranean, Stenomediterranean, W Mediterranean, Mediterranean Turanic, Mediterranean Pontic); CB: Circumboreal; PT: Paleotemperate; E (European, S European, Europ-Caucasian, E and SE European); An: Amfi-Atlantic; En: Endemic C: Cosmopolitan; SC: Subcosmopolitan; ST: Subtropical; NA: N American; L: Littoralic (LittoralicBlack Sea, Littoralic-Black Sea and Dagestan, Littoralic Black Sea and Caspian Sea); EA: Eurasian, Continental Eurasian; ES: Euro-Siberian; Po: Pontic (Pontic-Pannonic-Balkanic, Pontic-Panonic, Pontic-Mediterranean); GD: Getic-Dobrogean; TPDC: Tauric-Ponto-Dobrogean-Caspic; sERB: subEndemic (Romania, Bulgaria); sEP: sub-Endemic-Pontic;

Life forms - T : therophyte; Grhiz: rhizhomatous geophyte; Ch: chamaephyte; Hscap, Hros, Hrept, Hbienn: hemicryptophyte (with stem, with rosette only; creeping; biennal); Gb: bulb geophyte; P: phanerophyte

Table 3: Synoptic table of psammophytic habitats along Tuscany and Dobrogea coasts; the first number in the column is frequency in percent and the second is fidelity $=$ phi coefficient $\times 100$; diagnostic species (in bold) for the corresponding habitat are highlighted with symbols in brackets.

\begin{tabular}{|c|c|c|c|c|c|c|}
\hline Number of relevés & 17 & 19 & 27 & 17 & 23 & 20 \\
\hline Region & Tuscany & Tuscany & Tuscany & Dobrogea & Dobrogea & Dobrogea \\
\hline Habitat & H1210 (*) & H2110 $\left(^{\circ}\right)$ & H2120 $\left({ }^{\wedge}\right)$ & H1210 (*) & $\mathrm{H} 2110\left({ }^{\circ \circ}\right)$ & H2120 (^^) \\
\hline Cakile maritima (*) & $100 / 12.8$ & 36.8 & 33.3 & $82.4 / 17.8$ & 56.5 & \\
\hline Salsola kali (*) & $64.7 / 9.3$ & 15.8 & . & $94.1 / 42.4$ & 43.5 & 20 \\
\hline Elymus farctus $\left(^{\circ}\right)$ & 29.4 & $100 / 13.1$ & 40.7 & . & 13 & 40 \\
\hline $\begin{array}{l}\text { Sporobolus virginicus } \\
\left({ }^{\circ}\right)\end{array}$ & 17.6 & 31.6 & 14.8 & . & . & . \\
\hline Achillea maritima $\left({ }^{\circ}\right)$ & 5.9 & 57.9 & 11.1 & . & . & . \\
\hline $\begin{array}{l}\text { Eryngium maritimum } \\
(\circ \wedge)\end{array}$ & 35.3 & 73.7 & 77.8 & 64.7 & 78.3 & 60 \\
\hline
\end{tabular}




\begin{tabular}{|c|c|c|c|c|c|c|}
\hline $\begin{array}{l}\text { Echinophora spinosa } \\
\left({ }^{\wedge}\right)\end{array}$ & . & 57.9 & $66.7 / 10.7$ & . & & \\
\hline Euphorbia paralias $\left(^{\wedge}\right)$ & 17.6 & 84.2 & 70.4 & . & . & . \\
\hline Anthemis maritima $\left(^{\wedge}\right)$ & & & 14.8 & . & & \\
\hline Medicago marina $\left({ }^{\wedge}\right)$ & . & 10.5 & 25.9 & . & . &. \\
\hline $\begin{array}{l}\text { Ammophila arenaria } \\
\left({ }^{\wedge}\right)\left({ }^{\wedge} \wedge\right)\end{array}$ & & 36.8 & $92.6 / 38.4$ & . & & $100 / 72.0$ \\
\hline Medicago falcata $\left({ }^{\wedge \wedge}\right)$ & 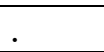 & . & . & . & 21.7 & $40 / 4.3$ \\
\hline Leymus racemosus $\left({ }^{\circ}\right)$ & & . & . & 58.8 & $91 / 50.8$ & 75 \\
\hline Crambe maritima $\left({ }^{\circ}\right)$ & & . & . & 35.3 & $78.3 / 11.4$ & 15 \\
\hline $\begin{array}{l}\text { Artemisia } \\
\text { tschernieviana }\left({ }^{\circ}\right)\end{array}$ & . & . & . & 10 & $26.1 / 24.2$ & . \\
\hline Xanthium italicum & 47.1 & . & . & 94.1 & 26.1 & \\
\hline Atriplex prostrata & 52.9 & . &. & 5.9 & 4.3 & . \\
\hline Calystegia soldanella & 11.8 & 42.1 & 66.7 &. & & \\
\hline Solidago litoralis &. & 36.8 & 37 &. & . & . \\
\hline Polygonum maritimum & 29.4 & 26.3 &. & 17.6 & . & . \\
\hline Euphorbia peplis & 52.9 & 36.8 & . & 17.6 & & . \\
\hline Glaucium flavum & 11.8 &. & 7.8 & 5.9 & 34.8 & . \\
\hline Cynodon dactylon & 11.8 &. &. & 23.5 & 21.7 & . \\
\hline Bromus madritensis & . & 10.5 & 25.9 & . &. & . \\
\hline Hypochaeris radicata & & 10.5 & 37 & . & . & . \\
\hline Lagurus ovatus & . & 5.3 & 22.2 & . & . & . \\
\hline Medicago littoralis & 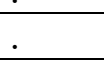 & 10.5 & 7.4 & . & & 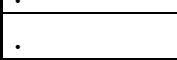 \\
\hline Oenothera biennis & . & 10.5 & . & . & . & \\
\hline Pancratium maritimum & . & 31.6 & 22.2 & \begin{tabular}{|c} 
\\
\end{tabular} & & 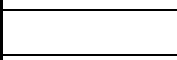 \\
\hline Pseudorlaya pumila & . & 15.8 &. & . & . & . \\
\hline Silene colorata &. & 15.8 & 44.4 & . & . & . \\
\hline Spartina versicolor & . & 42.1 & 11.1 & . & & . \\
\hline Vulpia fasciculata & . & 26.3 & 40.7 & . & & . \\
\hline Centaurea paniculata & . &. & 7.4 & . & . & . \\
\hline Crepis vesicaria & . & . & 14.8 & . & . & . \\
\hline Crithmum maritimum & & . & 11.1 & $\dot{.}$ & & \\
\hline Helichrysum stoechas & . & . & 70.4 & . &. & . \\
\hline Jacobaea maritima & . & . & 7.4 & . & . & . \\
\hline Juniperus oxycedrus & . & . & 7.4 & . & . & . \\
\hline Malcolmia ramosissima & & . & 7.4 & . & . & . \\
\hline Matthiola tricuspidata & & . & 3.7 & . & . & . \\
\hline Reichardia picroides &. & . & 7.4 & . & . & . \\
\hline Silene otites & . & . & 14.8 & . & & \\
\hline $\begin{array}{l}\text { Urospermum } \\
\text { dalechampii }\end{array}$ & . & . & 7.4 & . & . & . \\
\hline Gypsophila perfoliata & & . & . & 23.5 & 60.9 & \\
\hline Lactuca tatarica & . & . & . & 58.8 & 87 & 60 \\
\hline Argusia sibirica & . & . & . & 52.9 & 8.7 & 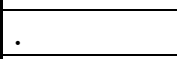 \\
\hline Scolymus hispanicus & . & . & . & 11.8 & 8.7 & \\
\hline Cynanchum acutum & & . & . & 29.4 & & 25 \\
\hline Corispermum nitidum & & . & . & 47.1 & 17.4 & \\
\hline Secale sylvestre & . & . & . & 29.4 & 21.7 & 35 \\
\hline Bromus tectorum & & . & . & 17.6 & 34.8 & 50 \\
\hline Alyssum hirsutum & . & . & . & 23.5 & 30.4 & 30 \\
\hline $\begin{array}{l}\text { Polygonum } \\
\text { oxyspermum }\end{array}$ & & $\cdot$ & . & 41.2 & \begin{tabular}{|l|}
17.4 \\
\end{tabular} & \\
\hline
\end{tabular}




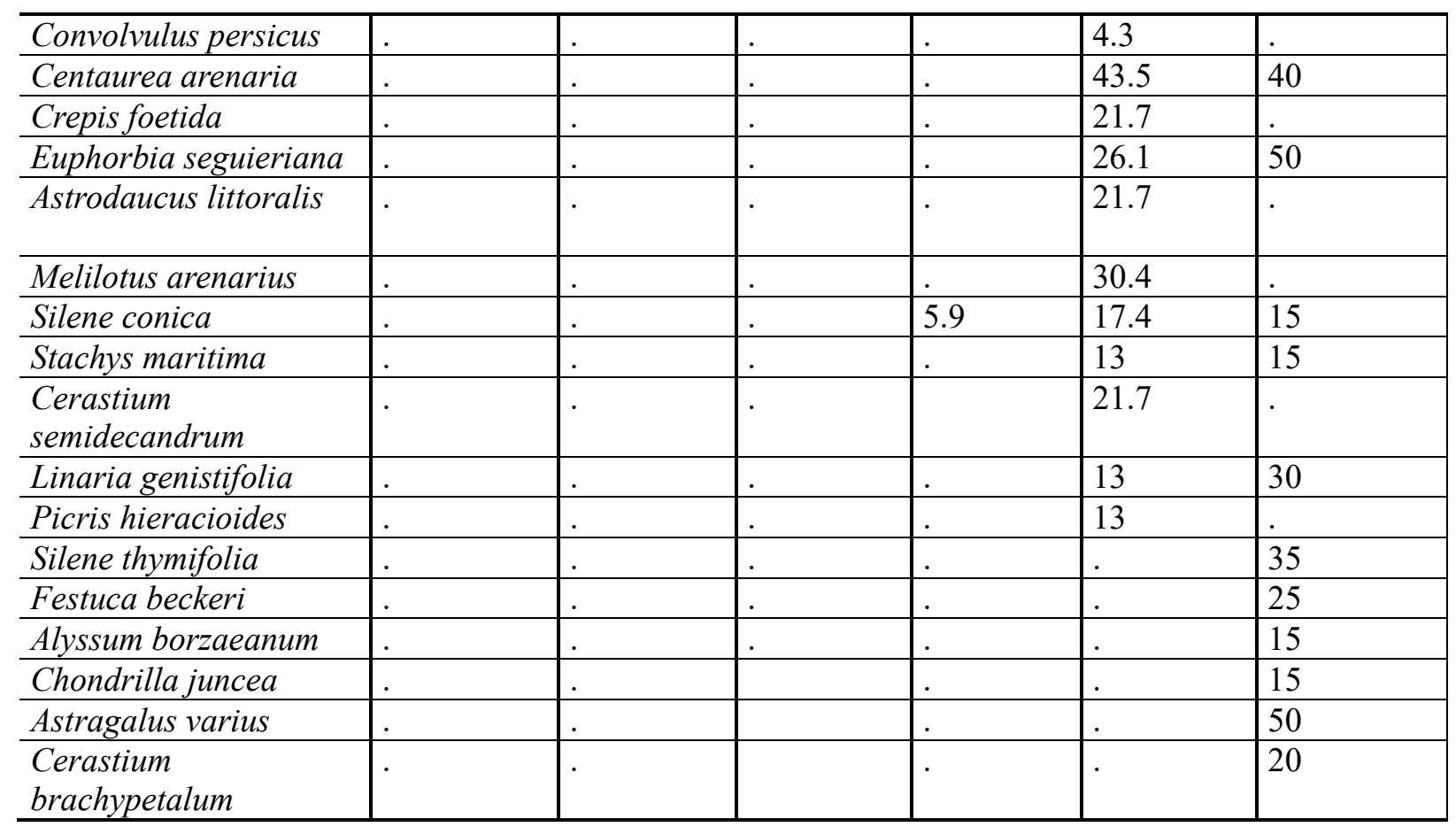

Sporadic (< 8\%) - Tuscany H1210: Hordeum murinum, Limbarda crithmoides, Plantago arenaria; H2110: Catapodium rigidum, Phleum arenarium, Reichardia picroides, Raphanus raphanistrum; H2120: Ononis variegata, Cutandia maritima, Crucianella maritima, Daucus carota, Dittrichia viscosa, Teucrium polium, Plantago coronopus, Fumana procumbens, Cuscuta cesatiana.

Dobrogea H1210: Petasites spurius, Plantago arenaria, Bassia hirsuta; H2110: Onosma arenaria, Verbascum banaticum, Aeluropus littoralis, Conyza canadensis, Hippophae rhamnoides; H2120 : Erysimum diffusum, Seseli tortuosum, Carex colchica, Scabiosa argentea, Anchusa officinalis, Bromus squarrosus, Stachys atherocalyx, Alyssum minutum, Xeranthemum annum, Verbascum purpureum, Papaver rhoeas, Aristolochia clematitis.

Table 4: Floristic comparison between the shared species of the dune habitats of the Tuscany coast and Dobrogea coast (* diagnostic 1210; ** diagnostic 2110; *** diagnostic 2120)

\begin{tabular}{|c|c|c|c|c|c|c|}
\hline & $\begin{array}{l}\operatorname{Max}^{\circ} \\
\text { of } \\
\text { species }\end{array}$ & $\begin{array}{c}\text { Average } n^{\circ} \\
\text { of species } \\
\text { per habitat } \\
( \pm \text { s.e. })\end{array}$ & $\begin{array}{l}\mathrm{N}^{\circ} \text { of } \\
\text { shared } \\
\text { specie } \\
\text { s }\end{array}$ & Shared species & $\begin{array}{l}\text { Main shared } \\
\text { species for each } \\
\text { habitat } \\
\text { (> } 30 \% \text { frequency } \\
\text { in both regions) }\end{array}$ & $\begin{array}{l}\text { Frequency } \\
(\%) \text { of } \\
\text { main } \\
\text { shared } \\
\text { species for } \\
\text { each habitat }\end{array}$ \\
\hline & $\begin{array}{l}\text { Tus } \\
\text { Dob }\end{array}$ & $\begin{array}{l}\text { Tus } \\
\text { Dob }\end{array}$ & & & & $\begin{array}{l}\text { Tus } \\
\text { Dob }\end{array}$ \\
\hline $\begin{array}{l}\text { All EU } \\
\text { foredune } \\
\text { habitats }\end{array}$ & $55 \quad 62$ & & 10 & $\begin{array}{l}\text { Cakile maritima } \\
\text { Salsola kali } \\
\text { Xanthium orientale } \\
\text { Elymus farctus } \\
\text { Ammophila } \\
\text { arenaria } \\
\text { Eryngium } \\
\text { maritimum } \\
\text { Polygonum } \\
\text { maritimum } \\
\text { Glaucium flavum } \\
\text { Cynodon dactylon } \\
\text { Atriplex prostrata }\end{array}$ & & . \\
\hline
\end{tabular}




\begin{tabular}{|c|c|c|c|c|c|}
\hline $\begin{array}{l}\text { EU habitat } \\
1210 \\
\text { Annual } \\
\text { vegetation } \\
\text { of drift } \\
\text { lines }\end{array}$ & $17 \quad 28$ & $\begin{array}{l}5.05 \\
8.05 \\
\pm 0.3 \\
\pm 0.3\end{array}$ & 8 & $\begin{array}{l}\text { Cakile maritima } \\
(*) \\
\text { Salsola kali }(*) \\
\text { Xanthium } \\
\text { orientale }\end{array}$ & $\begin{array}{l}100 \\
82.4 \\
64.7 \\
94.1 \\
47.1 \\
94.1\end{array}$ \\
\hline $\begin{array}{l}\text { EU habitat } \\
2110 \\
\text { Embryonic } \\
\text { shifting } \\
\text { dunes }\end{array}$ & $29 \quad 40$ & $\begin{array}{l}8.5 \\
10.04 \\
\pm 0.5 \\
\pm 0.6\end{array}$ & 4 & $\begin{array}{l}\text { Cakile maritima } \\
(*)\end{array}$ & $\begin{array}{l}36.8 \\
56.5\end{array}$ \\
\hline $\begin{array}{l}\text { EU habitat } \\
2120 \\
\text { Shifting } \\
\text { dunes } \\
\text { along the } \\
\text { shoreline } \\
\text { with } \\
\text { Ammophila } \\
\text { arenaria }\end{array}$ & $41 \quad 39$ & $\begin{array}{l}9.71 \\
8.65 \\
\pm 0.6 \\
\pm 0.6\end{array}$ & 3 & $\begin{array}{l}\text { Ammophila } \\
\text { arenaria }(* * *) \\
\text { Elymus farctus } \\
(* *)\end{array}$ & $\begin{array}{l}92.6 \\
100 \\
40.7 \\
40\end{array}$ \\
\hline
\end{tabular}

\section{REFERENCES}

1. Acosta, A.T.R., Ercole, S., Stanisci, A., De Patta Pillar, V., Blasi, C., 2007, Coastal vegetation zonation and dune morphology in some Mediterranean Ecosystems, Journal Coastal Research, 23: 1518-1524.

2. Acosta, A.T.R., Ercole, S., editors. 2015, Italian coastal dune habitats: ecology and conservation issues [Gli habitat delle coste sabbiose italiane: ecologia e problematiche di conservazione]. ISPRA, Serie Rapporti, Roma, 215/2015.

3. Angiolini, C., Viciani, D., Bonari, G., Lastrucci, L., 2017, Habitat conservation prioritization: A floristic approach applied to a Mediterranean wetland network, Plant Biosystems, 151: 598-612. DOI: $10.1080 / 11263504.2016 .1187678$

4. Barbour, M.G., 1992, Life at the leading edge: the beach plant syndrome. In: Seelinger, U., (ed.)., Coastal plant communities of Latin Americ,. Academic Press, New York.

5. Bertacchi, A., 2017, Dune habitats of the Migliarino - San Rossore - Massaciuccoli Regional Park (Tuscany Italy), Journal of Maps, 13: 322-331. DOI: 10.1080/17445647.2017.1302365

6. Bertacchi, A., Lombardi, T., 2014, Diachronic analysis (1954-2010) of transformations of the dune habitat in a stretch of the Northern Tyrrhenian Coast (Italy), Plant Biosystem, 148: 227-236. DOI: 10.1080/11263504.2013.788572

7. Bertacchi, A., Zuffi, M., Lombardi, T., 2016, Foredune psammophilous communities and coastal erosion in a stretch of the Ligurian sea (Tuscany, Italy), Rendiconti Scienze Fisiche Accademia Lincei, 4: 639-651. DOI: 10.1007/s12210-016-0543-5

8. Biondi, E., Burrascano, S., Casavecchia, S., Copiz, R., Del Vico, E., Galdenzi, D., Gigante, D., Lasen, C., Spampinato, G., Venanzoni, R., et al., 2012, Diagnosis and syntaxonomic interpretation of Annex I Habitats (Dir. 92/43/EEC) in Italy at the alliance level, Plant Sociology, 49: 5-37. DOI: 10.7338/pls2012491/01

9. Biondi, E., Blasi, C., Allegrezza, M., Anzellotti, I., Azzella, M., Carli, E., Casavecchia, S., Copiz, R., Del Vico, E., Facioni, L., et al., 2014, Plant communities of Italy: The Vegetation Prodrome, Plant Biosystems, 148: 728814. DOI: $10.1080 / 11263504.2014 .948527$

10. Biondi, E., Blasi, C., 2009, Italian interpretation manual of the 92/43/EEC Directive habitats. Ministero dell'Ambiente e della Tutela del Territorio e del Mare. http://vnr.unipg.it/habitat. Accessed 15 July 2018.

11. Bonari, G., Acosta, A.T.R., Angiolini, C., 2018, EU priority habitats: rethinking Mediterranean coastal pine forests, Rendiconti Lincei, Scienze Fisiche e Naturali, 29: 295-307. 
12. Braun-Blanquet, J., 1979, Phytosociology. Bases for the study of plant communities [Fitosociologia. Bases para el estudio de los comunidades vegetales],. Blume: Madrid.

13. Bray, J.R, Curtis, J.T., 1957, An ordination of upland forest communities of southern Wisconsin, Ecological Monographs, 27: 325-349.

14. Carboni, M., Zeleny, D., Acosta, A.T.R., 2016, Measuring ecological specialization along a natural stress gradient using a set of complementary niche breadth indices, Journal of Vegetation Science, 27: 892-903.

15. Carranza, M.L., Acosta, A., Stanisci, A., Pirrone, G., Ciaschetti G. 2008, Ecosystem classification and EU habitat distribution assessment in sandy coastal environments, Environmental Monitoring and Assessessing, 140: 99-107.

16. Chytrý, M., Hennekens, S.M., Jiménez-Alfaro, B., Knollová, I., Dengler, J., Jansen, F., et al., 2016, European Vegetation Archive (EVA): an integrated database of European vegetation plots, Applied Vegetation Science, 19: 173-180. DOI: $10.1111 /$ avsc. 12191

17. Conti, L., De Bello, F., Leps, J., Acosta, A.T.R., Carboni, M., 2017, Environmental gradients and microheterogeneity shape fine-scale plant community assembly on coastal dunes, Journal of Vegetation Science, 28: $762-777$

18. Dihoru, G., Negrean, G., 2009, Cartea roşie a plantelor vasculare din România, Editura Academiei Române: București.

19. Doing, H., 1985, Coastal foredune zonation and succession in various parts of the world, Vegetatio, 61: 65-75.

20. Doniţă, N., Popescu, A., Paucă-Comănescu, M., Mihăilescu, S., Biriş, I-A., 2005, Habitats in Romania, [Habitatele din România],. Editura Tehnică Silvică, București.

21. Doody, J.P., 2013, Sand dune conservation, management and restoration, Springer, Heidelberg.

22. Ellenberg, H., 1988, Vegetation ecology of Central Europe, University Press, Cambridge.

23. Evans, D., 2006, The habitats of the European union habitats directive, Biological Environment: Proceedings of the Royal Irish Academy, 106: 167-173.

24. Evans, D., 2010, Interpreting the habitats of Annex I. Past, present and future, Acta Botanica Gallica, 157: 677-686. DOI: 10.1080/12538078.2010.10516241

25. Făgăraş, M., Skolka, M., Anastasiu, P., Cogălniceanu, D., Negrean, G., Banică, G., Tudor, M., Samoilă, C., 2008, Biodiversity of the coastal area of Dobrogea between Cape Midia and Cape Kaliakra, Ex Ponto, Constanţa.

26. Făgăraş, M., 2012, Habitats of conservative interest and plant communities in the Black Sea coast area of Romania and Bulgaria, Journal of Environmental Protection and Ecology, 13: 1688-1694.

27. Feola, S., Carranza, M.L., Schaminée, J.H.J., Janssen, J.A.M., Acosta, A.T.R., 2011, EU habitats of interest: an insight into Atlantic and Mediterranean beach and foredunes, Biodiversity Conservation, 20: 1457-1468. DOI: 10.1007/s10531-011-0037-9

28. Gigante, D., Attorre, F., Venanzoni, R., Acosta, A.T.R., Agrillo, E., Aleffi, M., Alessi, N., Allegrezza, M., Angelini, P., Angiolini, C., et al., 2016, A methodological protocol for Annex I Habitats monitoring: the contribution of Vegetation science, Plant Sociology, 53: 77-87. DOI 10.7338/pls2016532/06.

29. Grime, J.P., 2006, Plant strategies, vegetation processes, and ecosystem properties, John Wiley \& Sons, Chichester.

30. Hammer, Ø., Harper, D.A.T., Ryan, P.D., 2001, Past: Paleontological Statistics Software Package for Education and Data Analysis. Palaeontologia Electronica. 4, issue 1, art. 4. http://palaeoelectronica.org/2001_1/past/issue1_01.htm.

31. Heslenfeld, P., Jungerius, P.D., Klijn, J.A., 2004, European coastal dunes: ecological values, threats, opportunities and policy development. In: Martinez, M.L., Psuty, N.P., (eds.) Costal dunes, ecology and conservation. Ecological studies vol 171,Springer-Verlag, Berlin.

32. Izzi, C.F., Acosta, A., Carranza, M.L., Ciaschetti, G., Conti, F., Di Martino, L., D’Orazio, G., Frattaroli, A., Pirone, G., Stanisci, A., 2007, Il censimento della flora vascolare degli ambienti dunali costieri dell'Italia centrale, Fitosociologia, 44: 129-137,

33. Jimenez-Alfaro, B., Marcenò, C., Guarino, R., Chytry, M., 2015, Regional metacommunities in two coastal systems: spatial structure and drivers of plant assemblages, Journal of Biogeography, 42: 452-462.

34. Mahdavi, P., Isermann, M., Bergmeie, E., 2017, Sand habitats across biogeographical regions at species, community and functional level, Phytocoenologia, 47: 139-165.

35. Maun, A., 2009, The biology of coastal sand dune,. Oxford University Press: Oxford. 
36. Medvedev, I.P., 2018, Tides in the Black Sea: Observations and Numerical Modelling, Pure and Applied Geophysics, 175: 1951-1969. https://doi.org/10.1007/s00024-018-1878-x

37. Mucher, C.A., Bunce, R.G.H., Hennekens, S.M., Shaminée, J.H.J., 2004, Mapping European habitat to support the design and implementation of a pan-European network: the PEENHAB project, Alterra report 952 , Wageningen

38. Mucina, L., Rutherford, M.C., Powrie, L.W., 2006, Inland azonal vegetation, The vegetation of South Africa, Lesotho and Swaziland, Strelitzia, 19: 617-657.

39. Nordstrom, K., Psuty, N., Carter, B., 1990, Coastal dunes: form and process, Wiley, Chichester.

40. Pignatti, S., 1982, Flora d'Italia, Edagricole, Bologna

41. Pignatti, S., 1993, Dry coastal ecosystems of Italy. In: Van Der Maarel, E., (ed.), Dry coastal ecosystems. Polar regions and Europe. Ecosystems of the world 2 A. Elsevier, Amsterdam.

42. Pranzini, E., 2004, The shape of the coasts. Coastal geomorphology, anthropic impact and defense of the coasts. [La forma delle coste. Geomorfologia costiera, impatto antropico e difesa dei litorali], Zanichelli, Bologna.

43. Prisco, I., Acosta, A.T.R., Ercole, S., 2012, An overview of the Italian coastal dune EU habitats, Annali di Botanica, 2: 39-48.

44. Raunkiaer, C.C., 1934, The Life Forms of Plants and Statistical Plant Geography, Oxford University Press, Oxford.

45. Rivas-Martìnez, S., Rivas-Saenz, S., 2015, Globalbioclimatics. http://www.bioclimatics.org. Accessed 20 Jul 2015.

46. Sârbu, I., Ştefan, N., Oprea, A., 2013, Plante vasculare din România. Determinator ilustrat de teren [Vascular plants of Romania. An illustrated field guide], Editura Victor B Victor, Bucureşti.

47. Šilc, U., Mullaj, A., Alegro, A., Ibraliu, A., Stevanović, Z.D., Luković, M., Stešević, D., 2016, Sand dune vegetation along the eastern Adriatic coast, Phytocoenologia, 46: 339-355.

48. Tichy', L., 2002, JUICE, software for vegetation classification, Journal of Vegetation Science, 13: 451-453.

49. Tichy', L., Chytry', M., 2006, Statistical determination of diagnostic species for site groups of unequal size, Journal of Vegetation Science, 17: 809-818.

50. Tzonev, R., Dimitrov, M., Roussakova, V., 2005, Dune vegetation of Bulgarian Black Sea coast, Hacquetia, 4 : 7-32.

51. Van der Maarel, E., Van der Maarel-Versluys, M., 1996, Distribution and conservation status of littoral vascular plant species along the European coasts, Journal of Coastal Conservation, 2: 73-92.

52. ***EUNIS. 2007, EUNIS habitat classification (revised descriptions 2012). https://www.eea.europa.eu/dataand-maps/data/eunis-habitat-classification.

53. ***Euro+Med PlantBase. 2006, The information resource for Euro-Mediterranean plant diversity. http://www.emplantbase.org/home.html._Accessed Jun 102018

54. ***ECDGE (European Commission DG Environment). 2007, Interpretation manual of European Union Habitats—EUR27. http://ec.europa.eu/environment/nature/legislation/habitatsdirective/docs/2007_07_im.pdf.

Accessed 10 Feb 2017

\section{ASEMĂNĂRI ŞI DEOSEBIRI ÎNTRE HABITATELE DE DUNE DE PE COASTELE TOSCANĂ ŞI DOBROGEANĂ (NORD-VESTUL ITALIEI VERSUS ROMÂNIA ŞI NORDUL BULGARIEI)}

\section{(Rezumat)}

Semnalăm şi comparăm habitatele de dune din unele zone localizate de-a lungul coastelor din Toscana (It) şi Dobrogea (Ro, Bu) concentrându-ne asupra caracteristicilor floristice şi fitocenotice, cu ajutorul releveelor fitosociologice facute de-al lungul ambelor coaste, care sunt foarte diferite din punct de vedere biogeografic. Ambele coaste au o lungime de circa $300 \mathrm{~km}$ si au aproape $200 \mathrm{~km}$ de plaje nisipoase. Dintre habitatele de dune (in sensul Directivei 92/43/EEC), sunt comune doar cele din partea superioară a dunelor şi cele de pe dunele mobile. Comparaţiile între releveele fitosociologice făcute în cele două zone, în aceste tipuri de habitate, au indicat următoarele: a) o diversitate floristică şi fitocenotică ridicată în acelaşi tip de habitat în cele două zone diferite de 


\section{A. BERTACCHI, M. FĂGĂRAŞ}

coaste nisipoase; b) o tendinţă de creştere a diferenţelor floristice de la habitatele de dune efemere (cu vegetaţie anuală) la dunele interne (dunele albe); c) speciile de diagnoză ale habitatelor sunt comune doar pentru habitatul 1210.

Received: 3.04.2019; Accepted: 25.10.2019. 